Meta

Journal des traducteurs

Translators' Journal

\title{
In Statistics, Errors Aren't Errors?
}

\section{Elaine Kennedy}

Volume 29, numéro 4, décembre 1984

URI : https://id.erudit.org/iderudit/003300ar

DOI : https://doi.org/10.7202/003300ar

Aller au sommaire du numéro

Éditeur(s)

Les Presses de l'Université de Montréal

ISSN

0026-0452 (imprimé)

1492-1421 (numérique)

Découvrir la revue

Citer cet article

Kennedy, E. (1984). In Statistics, Errors Aren't Errors? Meta, 29(4), 375-386.

https://doi.org/10.7202/003300ar d'utilisation que vous pouvez consulter en ligne.

https://apropos.erudit.org/fr/usagers/politique-dutilisation/ 


\section{ÉTUDES \\ TERMINOLOGIQUES \\ ET LINGUISTIQUES}

\section{IN STATISTICS, ERRORS AREN'T ERRORS ?}

Statistics is "a branch of mathematics dealing with the collection, analysis, interpretation, and presentation of masses of numerical data" 1 . However, statistical terminology is not peculiar only to mathematics. The behavioural sciences and engineering alike apply statistics, and consequently have contributed to the expansion and evolution of statistical language. A study of eighteen statistical terms will indicate in a small way that this progression is due to the semantic widening of established words, the creation of neologisms, borrowing between subject fields, and a modest move away from one particular appellation : that of error. To the layman, error might seem to refer to something gone quite awry, but in statistics, errors aren't errors, rather they denote the difference between the results obtained from a sample and those which would have been obtained from a census ${ }^{2}$.

The terms which form the subject of this study are :

$\begin{array}{ll}\text { accidental error } & \text { noncompensating error } \\ \text { bias } & \text { permissible error } \\ \text { biased error } & \text { random error } \\ \text { chance error } & \text { standard deviation } \\ \text { confidence interval } & \text { standard error } \\ \text { constant error } & \text { systematic error } \\ \text { error limit } & \text { tolerable error } \\ \text { limit of error } & \text { tolerance } \\ \text { margin of error } & \text { tolerance limit }\end{array}$

These terminology units had initially been extracted from various sources, some with their definitions and others without, for inclusion in a glossary. However, even the terms accompanied by their definitions were not readily distinguishable. As a result, the terms needed to be researched, classified and further defined so that they could be differentiated and their usage labels established. Thus the objective of this study.

The subsequent classification was developed based on the research carried out on the terms in question.

1. Webster's New Collegiate Dictionary (1975) : G. \& C. Merriam, p. 1137.

2. Maurice G. Kendall and William R. Buckland (1971) : A Dictionary of Statistical Terms, 3rd ed., Edinburgh, Oliver \& Boyd, p. 50. 


\section{Classification of Terms}

I. Errors

A. Non-Sampling : constant error ; systematic error ; noncompensating error ; biased error ; bias

B. Sampling : random error ; chance error ; accidental error

II. Estimate of Sample Precision

A. permissible error ; tolerable error

B. margin of error ; tolerance

C. limit of error ; error limit ; tolerance limit

III. Reliability of Estimate confidence interval

IV. Distribution standard deviation; standard error

Class IA terms, "Non-Sampling Errors", are errors which may be caused by "the procedure employed in defining, collecting, and processing the data, and may be present in either a sample or a census. ${ }^{31}$ This category includes constant error, systematic error, noncompensating error, biased error and bias. Class IB terms, "Sampling Errors", refer to errors which result from the act of drawing a sample as opposed to taking a census ${ }^{4}$. Class IB is composed of random error, chance error and accidental error. The relationship between Class IA and Class IB is that they are opposites as definition of their terms will indicate.

CLASS IA :

constant error

D. "An error affecting all of a set of measurements in the same manner ; an error ... which introduces a systematic bias into the measurements. Also called ... systematic error ...5"

D. "(Statistical). An error due to observational, instrumental, or other bias which persists in one direction and so cannot cancel out like a chance error ${ }^{6} . "$

O. "A - ... should be used strictly for something that is found in all cases 7 ."

O. "If measurement error is identical for every measurement, such error is referred to as -.... Identical error for every measurement is rare, but measurement error commonly includes a constant component ${ }^{8}$."

O. Constant error and random error are treated as antonyms ${ }^{9}$.

3. Richard C. Clelland, John S. deCani and Francis E. Brown, (1973) : Basic Statistics with Business Applications, 2nd ed., New York, John Wiley and Sons, p. 13.

4. Davis S. Moore (1979) : Statistics : Concepts and Controversies, San Francisco, W.H. Freeman and Company, p. 13.

5. Albert K. Kurtz and Harold A. Edgerton (1967) : Statistical Dictionary of Terms and Symbols, New York, Hafner, p. 35.

6. Thomas Ford Hoult (1974) : Dictionary of Modern Sociology, New Jersey, Littlefield Adams \& Co., p. 63.

7. Horace B. English and Ava C. English (1968) : A Comprehensive Dictionary of Psychological and Psychoanalytical Terms, New York, David McKay, p. 187.

8. John H. Mueller, Karl F. Schuessler and Herbert L. Costner (1977) : Statistical Reasoning in Sociology, 3rd ed., Houghton Mifflin, p. 24.

9. Ibid., p. 24. 
systematic error

D. "A statistical error that persists and cannot be considered as due entirely to chance - opposed to random error ${ }^{10}$."

D. "A nonrandom error which introduces bias into all the observations ; such an error might be caused by faulty, or poorly adjusted, measuring instruments ${ }^{11}$."

Ex. "Suppose that something was operating in our method or in our apparatus which caused us always to have an error which was on the high side. Errors such as these are described as - Their mean would not be zero ${ }^{12}$."

O. "-, or bias as it is often called ${ }^{13}$."

Noncompensating error appears, without a definition, in only one of the sources reviewed, consequently it will be defined in opposition to compensating error.

compensating error

D. "The kind of error that ... exhibits no consistent tendency in either direction ... that tends to balance or offset other such errors ... [and] that dos not introduce any systematic bias into the measurements ${ }^{14}$."

biased error ; biassed error

D. " - under-estimate [or overestimate] all the items [in a set] ... [and] all tend in the same direction ...15"

D. " - is consistently positive or negative. - may arise from different sources, eg., ... faulty data collection equipment or instrumentalities ...16"

O. Biased error appears primarily in sources published between 1939 and 196717 .

bias

D. "3. In sampling, a - is a systematic error introduced by selecting items from a wrong population, favoring some of the elements of a population, or poorly phrasing questions ${ }^{18} . "$

D. "Generally, an effect which deprives a statistical result of its representativeness by systematically distorting it, as distinct from a random error which may distort on any one occasion but which balances out on the average ${ }^{19}$."

10. Webster's Third New International Dictionary, (1971) : G. \& C. Merriam, p. 2323.

11. John E. Freund and Frank J. Williams (1966) : Dictionary/Outline of Basic Statistics, New York, McGraw-Hill, Inc., p. 107.

12. Richard C. Clelland, John S. deCani and Francis E. Brown (1973) : Basic Statistics with Business Applications, 2nd ed., New York, John Wiley \& Sons, p. 13.

13. Ibid.

14. Albert K. Kurtz and Harold A. Edgerton (1967) : Statistical Dictionary of Terms and Symbols, New York, Hafner, p. 32.

15. Arthur L. Bowley (1945) : An Elementary Manual of Statistics, London, Macdonald and Evans, p. 32.

16. Joseph E. Hill and August Kerber (1967) : Models, Methods and Analytical Procedures in Education Research, Detroit, Wayne State University Press, p. 50.

17. Biased error appears in the texts quoted at footnote 14 (copyright 1939), 15 (1945), 24 (1958, p. 186), 27 (1966, p. 403) and 16 (1967). It was also found in Lillian Cohen (1954): Statistical Methods for Social Scientists : An Introduction, New York, Prentice-Hall, p. 80. The term was not found in any of the sources consulted that were published after 1967, and it is for this reason that the term is assumed to be dated.

18. John E. Freund and Frank J. Williams (1966) : Dictionary/Outline of Basic Statistics, New York, McGraw-Hill, p. 10.

19. Maurice G. Kendall and William R. Buckland (1971) : A Dictionary of Statistical Terms, Edinburgh, Oliver \& Boyd, p. 14. 
Table 1

Class $1 \mathrm{~A}$ : Non-Sampling Errors

\begin{tabular}{|c|c|c|c|}
\hline Terms & Nature & Cause & Behaviour \\
\hline constant error & $\begin{array}{l}\text {-statistical error } \\
\text {-constant }\end{array}$ & $\begin{array}{l}\text {-observational, } \\
\text { instrumental or } \\
\text { other bias }\end{array}$ & $\begin{array}{l}\text {-persists in one } \\
\text { direction } \\
\text {-cannot cancel out }\end{array}$ \\
\hline systematic error & $\begin{array}{l}\text {-statistical error } \\
\text {-systematic } \\
\text {-nonrandom } \\
\text {-nonchance }\end{array}$ & $\begin{array}{l}\text {-faulty or poorly } \\
\text { adjusted measuring } \\
\text { instruments }\end{array}$ & $\begin{array}{l}\text {-persists in one } \\
\text { direction } \\
\text {-the mean of these } \\
\text { errors is not zero }\end{array}$ \\
\hline $\begin{array}{l}\text { noncompensating } \\
\text { error }\end{array}$ & $\begin{array}{l}\text {-error } \\
\text {-noncompensating }\end{array}$ & & $\begin{array}{l}\text {-exhibits consistent } \\
\text { tendency in one } \\
\text { direction } \\
\text {-does not tend to } \\
\text { balance or offset } \\
\text { other such errors }\end{array}$ \\
\hline $\begin{array}{l}\text { biased error } \\
\text { biassed error }\end{array}$ & $\begin{array}{l}\text {-error } \\
\text {-biased }\end{array}$ & $\begin{array}{l}\text {-faulty data } \\
\text { collection } \\
\text { equipment or } \\
\text { instrumentalities }\end{array}$ & $\begin{array}{l}\text {-consistently tends to } \\
\text { be in the same } \\
\text { direction }\end{array}$ \\
\hline bias & $\begin{array}{l}\text {-error } \\
\text {-systematic }\end{array}$ & $\begin{array}{l}\text {-selecting items from } \\
\text { a wrong population } \\
\text {-poor phrasing of } \\
\text { questions }\end{array}$ & $\begin{array}{l}\text {-unlike random error } \\
\text { therefore distorts in } \\
\text { one direction and } \\
\text { does not balance out } \\
\text { on the average }\end{array}$ \\
\hline
\end{tabular}

O. Toward the end of the 1960 s, the term bias, which at that time was already polysemic in statistics, was extended semantically to include the meaning of systematic error and has since been used synonymously with systematic error ${ }^{20}$.

20. The term bias as it is defined in the source quoted at footnote 14, which was reprinted in 1967 but whose copyright date is 1939, does not include the meaning of systematic error. In the source quoted at footnote 18 above, bias has been extended to mean systematic error. In the 1971 edition of Webster's, bias dos not mean systematic error, but in the 1975 edition it does. Moreover, from 1973 on, specialized sources such as that referred to at footnote 13 and the International Encyclopedia of Statistics, vol. 1, William H. Kruskal and Judith M. Tanur editors (1978) : New York, The Free Press, p. 208, employ bias and systematic error synonymously. 
Table 1 (cont'd)

\begin{tabular}{|c|c|c|c|}
\hline Effect & Synonyms & Antonyms & Observations \\
\hline $\begin{array}{l}\text {-affects all of a set } \\
\text { of measurements in } \\
\text { the same manner } \\
\text {-introduces a } \\
\text { systematic bias into } \\
\text { the measurements }\end{array}$ & -systematic error & $\begin{array}{l}\text {-chance error } \\
\text {-random error }\end{array}$ & $\begin{array}{l}\text {-strictly for } \\
\text { something found in } \\
\text { all cases } \\
\text {-identical for every } \\
\text { measurement, which } \\
\text { is rare }\end{array}$ \\
\hline $\begin{array}{l}\text {-introduces bias into } \\
\text { all the observations }\end{array}$ & -bias & -random error & -often called bias \\
\hline \multicolumn{4}{|l|}{$\begin{array}{l}\text {-introduces } \\
\text { systematic bias into } \\
\text { the measurements }\end{array}$} \\
\hline $\begin{array}{l}\text {-underestimates or } \\
\text { over-estimates all } \\
\text { items in a set }\end{array}$ & & & $\begin{array}{l}\text {-appears in texts } \\
\text { ranging from } 1939 \\
\text { to } 1967\end{array}$ \\
\hline $\begin{array}{l}\text {-deprives a statistical } \\
\text { result of its } \\
\text { represent-ativeness } \\
\text { by systematically } \\
\text { distorting it }\end{array}$ & -systematic error & -random error & $\begin{array}{l}\text {-in the late } 1960 \mathrm{~s} \text {, } \\
\text { bias was widened } \\
\text { semantically to } \\
\text { include the meaning } \\
\text { of systematic error }\end{array}$ \\
\hline
\end{tabular}

Table 1 indicates that Class IA terminology units are largely synonymous as they all refer to statistical errors which arise from similar causes, behave in approximately the same manner, and produce the same effect. In this respect, they may be referred to as synonyms of the same semantic notion. It is, however, possible to differentiate these terms according to their usage. Although some authors employ constant error and systematic error interchangeably, other authors suggest that constant error is more restrictive. Moreover, systematic error appears much more frequently than dces constant error. Systematic error and bias may be distinguished as the former has only one meaning while the latter is polysemic. Thus, their relationship is specific - generic. Noncompensating error differs from its synonyms since it appears to be a neologism, formed by adding the prefix non-to the established compound, compensating error. The fact that it appeared in only one of the sources reviewed would further indicate that its use is rare. Biased error, or its seldom used spelling variant biassed error, is distinctive because it is dated, and appears to have been succeeded by the more concise appellation bias, which has been widened semantically to refer to systematic error. 
The results of this brief study may be summarized as follows :

Terms

systematic error $F^{*}$

$\operatorname{bias}^{G}$
Synonyms

constant error ${ }^{R S}$

noncompensating error $\mathrm{N} / \mathrm{R}$

biased error ${ }^{\mathrm{D}}$

systematic error $\mathbf{S}$

Just as the definitions of Class IA indicated opposition to Class IB, so will the definitions of Class IB indicate opposition to Class IA.

CLASS IB :

random error

D. "A - exhibits no systematic tendency to be either positive or negative and is assumed to average to $\mathrm{O}$ over a large number of subjects of trials ${ }^{21}$."

D. "A statistical error that is wholly due to chance and dœs not recur - opposed to systematic error 22 ."

D. " - ... behave in predictable ways, ... cancel each other and their effect is nullified 23 ."

chance error

D. "1. that part of the variability of a set of observations or scores that can be attributed to chance. It will depart from the true value as much and as often in one direction as the other, so that the sum of - for a large number of cases aproaches zero. Syn. ... random error ... Contr. constant error, systematic error ...

2. the mean deviation of a sample from the mean of a very large number of observed values. In this usage the mean is taken as the true value, and it is assumed that the average deviation of the sample is due to chance. Syn. sampling error (much prefd. $)^{24 . "}$

accidental error

D. " - An unpredictable departure from the true value of a measurement. In practice, the mean of a large series of measurements ... is taken to be the true value ; the - is the difference from this mean ... It is assumed to be due to ... chance factors ... Syn. chance error ...25"

* (List of Usage Labels : $\mathrm{B}=$ borrowing ; $\mathrm{D}=$ dated ; $\mathrm{F}=$ frequently used ; $\mathrm{G}=$ generic ; $\mathrm{N}=$ neologism $; \mathrm{NP}=$ not preferred $; \mathbf{R}=$ rare $; \mathrm{RS}=$ restrictive $\mathbf{S}=$ specific)

21. George A. Ferguson (1976) : Statistical Analysis in Psychology \& Education, 4th ed., New York, McGraw-Hill, p. 423.

22. Webster's Third New International Dictionary (1971) : G. \& C. Merriam, p. 1880

23. John H. Mueller, Karl F. Schuessler and Herbert L. Costner (1977) : Statistical Reasoning in Sociology, 3rd ed., Houghton Mifflin, p. 24.

24. Horace B. English and Ava C. English (1958) : A Comprehensive Dictionary of Psychological and Psychoanalytical Terms, New York, David McKay, p. 187.

25. Ibid., p. 5 . 
According to the breakdown of Class IB definitions in Table 2, Class IB terms are synonyms of the same semantic field as they all share an overall element of meaning : they are all statistical errors due to chance. Nevertheless, their specific meanings are different. The definition of random error and the first definition of chance error correspond to a large degree, however the latter is polysemic thus generic whereas the former is specific. Furthermore, chance error is used in this sense but rarely while random error is frequently employed. Chance error in its second meaning was found in a few of the sources consulted, nonetheless, sampling error, although beyond the scope of this study, is a more common and much preferred designation. The definition of accidental error and the second definition of chance error are very similar, however chance error is generic while accidental error is both specific and rare. The nature and cause of random error and accidental error are alike, yet these terms may be distinguished as their behaviour and effect are descrepant.

The relationship among these terms is as follows :

Terms random errors/F chance error $\mathrm{G} / \mathrm{NP}$

Synonyms chance error $G / R$ accidental error $\mathbf{S} / \mathbf{R}$

Class II terms, Estimate of Sample Precision, refer to the desired sample accuracy which is determined according to the use to which the sample results will be put ${ }^{26}$. The terms included in this category are : A. permissible error, tolerable error; B. margin of error, tolerance; and C. limit of error, error limit and tolerance limit. They will be defined together, however the definitions of Group A will be examined separately from those of Group $B$ and $C$ as the latter two require a different type of analysis. The relationship among the three groups in this class will then be discussed.

CLASS IIA :

permissible error

D. "The - is the largest deviation from the true value which would be acceptable to the sponsor or which would permit the surveyor to solve the essential question ... of the survey ${ }^{27} . "$

D. "[The amount] the percentage to be secured from the sample [may] vary from the true (unknown) value for the universe or population and still be acceptable ...28"

tolerable error

Ex. "[Separating] insignificant errors from decidedly undesirable [is necessary] ... All error is undesirable, but some error must be accepted as the price for using a sample instead of a census. ... Reducing the chance of error increases reliability. Thus we may speak of reliability in terms of the probability that the estimate will differ from the parameter's true value by no more than the - $29 . "$

26. William G. Cochran (1977) : Sampling Techniques, 3rd ed., John Wiley \& Sons, p. 74.

27. Wildred Parten (1966) : Surveys, Polls, and Samples: Practical Procedures, New York, Cooper Square Publishers, p. 306.

28. Ibid., p. 305 .

29. Lawrence Lapin (1978) : Statistics for Modern Business Decisions, 2nd ed., Harcourt Brace Jovanovich, p. 258. 
Table 2

Class 1B : Sampling Errors

\begin{tabular}{|c|c|c|c|}
\hline Terms & Nature & Cause & Behaviour \\
\hline -random error & $\begin{array}{l}\text {-statistical error } \\
\text {-random }\end{array}$ & -chance & $\begin{array}{l}\text {-no systematic } \\
\text { tendency to be } \\
\text { positive or negative } \\
\text {-average to } 0 \\
\text {-dos not recur } \\
\text { - predictable } \\
\text {-cancel each other }\end{array}$ \\
\hline & $\begin{array}{l}\text {-error } \\
\text {-chance }\end{array}$ & -chance & $\begin{array}{l}\text {-departs as much } \\
\text { and as often in one } \\
\text { direction as the } \\
\text { other } \\
\text {-sum approaches } 0\end{array}$ \\
\hline & $\begin{array}{l}\text {-error } \\
\text {-chance }\end{array}$ & -chance & $\begin{array}{l}\text {-deviates from true } \\
\text { value }\end{array}$ \\
\hline -accidental error & $\begin{array}{l}\text {-error } \\
\text {-accidental }\end{array}$ & -chance & $\begin{array}{l}\text {-departs } \\
\text { unpredictably from } \\
\text { true value }\end{array}$ \\
\hline
\end{tabular}

\section{CLASS IIB :}

\section{tolerance}

Ex. "Under conditions of randomness, the sampling variability has ... a range or " with and associated degree of probability 30 .

Ex. "The chances that the particular sample drawn in the survey will yield an estimate of the universe which is within the permissible error depend upon the variation among samples drawn from that universe. If the samples tend to deviate considerably from the true value, then the chances of any given sample staying within the permissible limits are not so good ; ... if the samples tend to deviate only slightly from the true value, the chances of not exceeding the - are better ${ }^{31}$."

D. "3. (Stat., Mech.) the amount of deviation from a standard that is permitted...32"

D. "Included in the specifications [of the characteristics of an item] will necessarily be a statement of the permitted variation of the item to be produced; these are which are to be allowed in acceptable items ${ }^{33}$."

30. William Edwards Deming (1950) : Some Theory of Sampling, New York, John Wiley \& Sons, p. 19

31. Wildred Parten (1966) : Surveys, Polls, and Samples : Practical Procedures, New York, Cooper Square Publishers, p. 307.

32. Horace B. English and Ava C. English (1958) : A Comprehensive Dictionary of Psychological and Psychoanalytical Terms, New York, David McKay, p. 555.

33. Albert D. Rickmers and Hollis N. Todd (1967) : Statistics : An Introduction, McGraw-Hill, p. 555. 
Table 2 (cont'd)

\begin{tabular}{|c|c|c|c|}
\hline Effect & Synonyms & Antonyms & Observations \\
\hline- nullified & & -systematic error & \\
\hline -thus, null & -random error & -systematic error & \\
\hline -thus, difference & -sampling error & $\begin{array}{l}\text {-sampling error } \\
\text { much preferred }\end{array}$ & \\
\hline -thus, difference & & -chance error & \\
\hline
\end{tabular}

O. "The '- terminology is especially common in fitting together manufactured parts ${ }^{34}$."

margin of error

D. " - ... The amount of difference between the sample findings about a given sample and comparable findings about the universe from which the sample was drawn thus, when ... [the] sample findings and the population findings are within five percent of one another, the percentage figure is termed the $-\ldots 5^{\prime \prime}$

CLASS IIC :

error limit ;

limit of error

Ex. "Sometimes it is difficult to decide how much error should be tolerated ... We asked the anthropologist why he wished the percentage with blood group o to be correct to $5 \%$ instead of ... 4 or $6 \%$... An - of $5 \%$ in the estimate seemed to him small enough ... He would, however, have no violent objection to 4 or $6 \%$ - $^{36}$."

tolerance limit

Ex. "This gives effective degrees of freedom ... with corresponding limits for the percentage ... outside the - of 6.6 to 28.6 per cent ${ }^{37}$."

D. "An upper and lower value of a variate ....38"

D. "The limiting values between which measurements must lie if an article is to be acceptable...39"

34. B.W. Lindgren and G.W. McElrath (1969) : Introduction to Probability and Statistics, 3rd ed., MacMillan, p. 119.

35. Thomas Ford Hoult (1974) : Dictionary of Modern Sociology, New Jersey, Littlefield, Adams \& Co., p. 192.

36. William G. Cochran (1977) : Sampling Techniques, 3rd ed., John Wiley \& Sons, p. 77.

37. D.R. Cox and E.J. Snell (1931) : Applied Statistics : Principles and Examples, Chapman and Hall, p. 142

38 Maurice G. Kendall and William R. Buckland (1971) : A Dictionary of Statistical Terms, Edinburgh, Oliver \& Boyd, p. 145.

39. Ibid. 
Table 3

Class IIA : Estimate of Sample Precision

\begin{tabular}{|c|c|c|c|}
\hline Terms & Nature & Cause & Behaviour \\
\hline \multirow[t]{2}{*}{ permissible error } & $\begin{array}{l}\text {-error } \\
\text {-permissible }\end{array}$ & & $\begin{array}{l}\text {-varies from the true } \\
\text { value for the } \\
\text { universe }\end{array}$ \\
\hline & $\begin{array}{l}\text {-deviation } \\
\text { - acceptable } \\
\text {-expressed as a } \\
\text { percentage }\end{array}$ & & $\begin{array}{l}- \text {-permissible, thus } \\
\text { insignificant }\end{array}$ \\
\hline tolerable error & $\begin{array}{l}\text {-error } \\
\text {-tolerable }\end{array}$ & $\begin{array}{l}\text {-using a sample } \\
\text { instead of a census }\end{array}$ & $\begin{array}{l}\text {-differs from } \\
\text { parameter's true } \\
\text { value } \\
- \text {-insignificant }\end{array}$ \\
\hline
\end{tabular}

Class IIA terms, permissible error and tolerable error are synonyms of the same semantic notion as they agree in nature, behaviour and effect. Moreover, sources indicate that they both result from taking a sample rather than a census. They are also coinciding synonyms for they are used interchangeably in the same subject field. Their only differentiating feature is that tolerable error appears slightly more frequently in the literature reviewed and often in conjunction with the other members of the tolerance family : tolerance and tolerance limit.

Table 4

Class II B and C : Estimate of Sample Precision

\begin{tabular}{llll} 
Terms & Nature & Function & Context \\
\hline B. & -range & $\begin{array}{l}\text {-encompasses } \\
\text { amount of } \\
\text { permitted deviation }\end{array}$ & -statistics \\
tolerance & -range & $\begin{array}{l}\text {-specifies variation } \\
\text { permitted in } \\
\text { production of an } \\
\text { item }\end{array}$ & $\begin{array}{l}\text {-manufacturing or } \\
\text { engineering }\end{array}$ \\
\hline -margin of error & -margin for error & $\begin{array}{l}\text {-encompasses } \\
\text { difference between } \\
\text { sample findings and } \\
\text { true value for } \\
\text { universe }\end{array}$ & $\begin{array}{l}\text {-statistical } \\
\text { applications in the } \\
\text { behavioural sciences }\end{array}$ \\
& percentage & & \\
& & &
\end{tabular}




\begin{tabular}{llll}
$\begin{array}{l}\text { C. error limit limit } \\
\text { of error }\end{array}$ & $\begin{array}{l}\text {-limits for error } \\
\text {-expressed as a } \\
\text { percentage }\end{array}$ & $\begin{array}{c}\text {-defines amount of } \\
\text { tolerable error }\end{array}$ & $\begin{array}{c}\text {-statistical } \\
\text { applications in the } \\
\text { behavioural sciences }\end{array}$ \\
\hline & $\begin{array}{l}\text {-an upper and lower } \\
\text { value }\end{array}$ & $\begin{array}{l}\text {-defines (permitted) } \\
\text { variation }\end{array}$ & -statistics \\
\hline tolerance limit_limiting values & $\begin{array}{l}\text {-defines acceptable } \\
\text { variation of } \\
\text { measurements }\end{array}$ & $\begin{array}{l}\text {-manufacturing or } \\
\text { engineering }\end{array}$ \\
\hline
\end{tabular}

Table 4 indicates that while the first definition of tolerance and the definition of margin of error correspond, these terms differ on many levels. Tolerance has been adopted by statistics from engineering, perhaps as a result of statistical applications in this field, and may thus be regarded as an internal borrowing. Moreover, it is polysemic, consequently generic, unlike margin of error which remains specific. Margin of error is used in a more specific context, i.e., that of the behavioural sciences, whereas tolerance has become well rooted in statistical terminology in general. Tolerance appears much more frequently than its synonym, is a more concise appellation and has the advantage of providing an alternative to using a compound containing the term error.

Class IIC terms, tolerance limit and limit of error, or the rarely used error limit differ in the same manner as Class IIB terms. In addition to being an internal borrowing, tolerance limit is polysemic thus generic, while limit of error is specific. Tolerance limit is found more often in a wide range of statistical sources, while limits of error is seldom used, and at that, in behavioural science texts. Similar to tolerance, tolerance limit offers an alternative to using a compound containing the word error.

The relationship among the terms included in Class II is that B refers to the range or margin for error, $\mathrm{C}$ designate the limits of this range, and $\mathrm{A}$ is the error which lies within the range. The discussion of Class II terms may be summarized as follows :
Terms
A. tolerable error $\mathrm{F}$
B. tolerance $\mathrm{B} / \mathrm{G} / \mathrm{F}$
C. tolerance limit ${ }^{\mathrm{B} / \mathrm{G} / \mathrm{F}}$

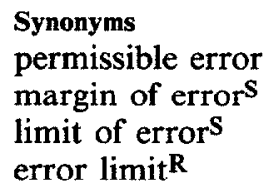

Class III, Reliability of Estimate, refers to the high degree of probability that a sample will represent what it is intended to estimate. In theory, if a large number of samples were drawn from a population, according to the laws of probability, 95 percent of the samples would be representative of the population in question. This is commonly referred to by statisticians as the 95 percent confidence interval ${ }^{40}$. Confidence interval is defined as "an interval for which one can assert with a given probability ..., called the degree of confidence..., that it will contain the parameter it is intended to estimate ${ }^{41}$." As confidence interval is not synonymous with any of the other terms under study, it remains in this class on its own.

40. Herbert Weisberg and Bruce Bowen, An Introduction to Survey Research and Data Analysis, W.H. Freeman and Company, p. 22.

41. John E. Freund and Frank J. Williams (1966) : Dictionary/Outline of Basic Statistics, New York, McGraw-Hill, p. 20. 
The final category, Class IV, is entitled Distribution, which refers to the over-all scattering of observed data ${ }^{42}$. The terms included in this category are standard deviation and standard error, which are measures of distribution as their definitions will indicate.

\section{standard deviation}

D. "The - is a measure of to what degree items are clustered (or scattered) around the mean...43"

D. " - ... is by far the most widely used measure of the variation of a set of data ...44"

\section{standard error}

D. "- The standard deviation of the sampling distribution of a statistic 45 ."

D. "Through the use of the measure known as the - , the ... researcher can make a reasonable estimate of the range within which any variation between the measure he gets from a sample and the measure he would have got from the whole population $\operatorname{lies}^{46}$."

Table 5

Class IV : Distribution

\begin{tabular}{lll} 
Terms & Nature & Function \\
\hline standard deviation & $\begin{array}{l}\text {-standard measure } \\
\text { of variation }\end{array}$ & $\begin{array}{c}\text {-determines degree to which items are } \\
\text { clustered or scattered aroud the mean }\end{array}$ \\
\hline standard error & $\begin{array}{l}\text {-standard measure } \\
\text { of error } \\
\text {-standard deviation }\end{array}$ & $\begin{array}{c}\text {-determines the degree to which sample } \\
\text { results will differ from true value or mean }\end{array}$ \\
\hline
\end{tabular}

The breakdown of Class IV term definitions in Table 5 shows that standard deviation and standard error are not synonymous as their nature and function are at odds. It should be pointed out, however, that these terms are sometimes confused because standard error uses standard deviation.

This study, which is by no means exhaustive, has attempted to fulfill the objective of classification, defining and differentiating the list of subject terms, in addition to establishing their usage labels. Moreover, it has given a brief glimpse into the world of statistical terminology. Statistics appears to have eliminated one word from its vocabulary, biased error, but has enriched its collection through neology, in the case of noncompensating error, through the semantic widening of bias, and through borrowing tolerance and tolerance limits from engineering, thus finding an alternative to designations containing the term error.

ELAINE KENNEDY

\footnotetext{
42. Ibid., p. 33.

43. James M. Livingston (1977) : A Management Guide to Market Research, London, Macmillan, p. 45.

44. John E. Freund and Frank J. Williams (1966) : Dictionary/Outline of Basic Statistics, New York, McGraw-Hill, p. 103.

45. Ibid., p. 104.

46. James M. Livingstone (1977) : A Management Guide to Market Research, London, Macmillan Press, p. 45.
} 